Najimdeen BAKARE

Centre for International Peace and Stability

DOI : $10.14746 /$ ps.2019.1.3

- NUST University Islamabad

https://orcid.org/0000-0003-3257-9718

Minahil R. TOOR

Centre for International Peace and Stability - NUST University Islamabad

https://orcid.org/0000-0002-6294-6462

\title{
REVISITING MACKINDER'S HEARTLAND THEORY: IDENTIFYING THE EMERGENCE OF A COMPLEX POWER COMPETITION IN THE INDIAN OCEAN REGION
}

\section{INTRODUCTION}

International politics remain in a continuous cycle of revising the means and course of state interactions. During the World Wars, hegemonic endeavours were focused to secure larger territorial areas and thereby, larger spheres of influence. However, the strings of contemporary state politics are held by geo-economic interests, being governed by realist aspirations in the backdrop. Such waves of international relations may be interpreted through theoretical underpinnings that have asserted their utility over the period of time. In 1904, Sir Halford Mackinder laid basis for countries to attain world dominance. In his heartland theory, he tagged Eastern Europe as the heartland, and argued that whoever has control over it, commands the world islands. It was a very popular motive for the Nazis during World War II. This concept received much acceptance from Soviet Union during the Cold War as well.

This paper probes whether Mackinder's heartland theory is still relevant for same areas identified by him or the same theory may be useful in other areas. The paper believes the heartland theory can be borrowed and situated in non-Mackinder's region of reference, in order to establish a wider utility for it in the present day power politics. Under this context, the paper draws a line around the Indian Ocean region and regards it as the neo-pivot area (under Mackinder's point of reference). After meticulous reestablishment of Mackinder's pivot area, the paper highlights that states are saturating on the ports surrounding the Indian Ocean region for economic, political, and military purposes. This makes a case for the paper to attest its argument that a complex power competition is taking roots in the neo-pivot area of influence. Such a competition pushes states to counter balance each other, with an ultimate goal of achieving maritime hegemony. Methodologically, the paper employs a qualitative approach. It does not develop a new theory, but rather builds on the existing geopolitical theory of Mackinder to explaining the geostrategic importance of the Indian Ocean. Such 
utility did not simply add to our understanding of geopolitics on the Indian Ocean, it equally demonstrates the instrumental role of theory vis-à-vis conceptualisation and contextualisation.

\section{REVISITING MACKINDER'S HEARTLAND THEORY}

Geopolitics is commonly associated with a particular mode of visualising space, states and the relations between them. Often this takes the form of mapping and emphasising the strategic importance of particular places (Sidaway, 2001: 225). Most geopolitical scientists or political geographers would agree that the term geopolitics is not just elusive, it is also transformational, it changes in different historical and geographical contexts. The implication of such dialectic is situated in the contextual importance accorded to a place at a given point in time.

Political geography has long been an important factor in state's calculus vis-à-vis other states. History remains indelible of how states choose to remain at peace or go to war due to geographical factors. The consideration of building a kingdom, empire, or state is amongst other reasons factored by political geography. In this backdrop, Mackinder's heartland theory reinforces the importance of geography and laid the theoretical foundation, upon which modern empires and states would find reasons to compete and rival over land and resource directly or otherwise not in their possession (Mackinder, 1904). In 1904, Mackinder laid the foundation of his world model, which is generally known as the theory of "Pivot Area". The theory suggests that the development of the potential power of the core area of Eurasia could enable any power who controls the area to dominate the world. Fifteen years later, Mackinder further refined the "Pivot Area" to the "Heartland" and hence the famous quote, "Who rules East Europe commands the Heartland; who rules the Heartland commands the World-Island; who rules the World-Island commands the world." (Mackinder, 1942: 50).

Mackinder reemphasised the strategic importance and competition between land and sea power (Mackinder, 1904; Mackinder, 1943; Weigert, 1945-46), and why it is essential that the British Empire (or any other power) makes no slack policy, to ensuring a balance over sea and land. According to Mackinder, had the Vikings not mastered sea navigation, "the penetration of inland by the river ways" the occupation of the northern and southern shores of Europe could and might not had been part of history (Mackinder, 1904: 427-428). Establishing the complex intersection between geography and human nature, Mackinder asserts that geographies are made, reconstructed and redefined by the dynamism of human activism in the form of domination (Mackinder, 1904). Mackinder presented the world a provocative contribution to the understanding of geography in the form of heartland theory, which is akin to the Admiral Mahan's world ocean theory. While both heartland and world ocean stress areas requisite for world dominion, Meinig argues that Mackinder's theorisation of geography and human nature remain within "the fluid complex of human affairs" (Meinig, 1956: 554).

Though the theory was propounded in 1904, but until now, it remains virtually the most cited in all geopolitical discourse and also continues to inform debate on foreign policy and shapes state's strategic calculus (Bassin, Aksenov, 2006; Taylor, Flint, 
2000: 53). It might be more than a century old, but the essence of the theory remains vital as a geographical formula in understanding the politics amongst great powers, with particular reference to how empires and modern states seek "sovereign living space" within their immediate and distant areas of jurisdiction, and in the "supposedly international space" (Hall, 1955; Sidaway, 2001; Scott, Alcenat, 2008).

\section{STRATEGIC IMPORTANCE OF THE INDIAN OCEAN AND ADJOINING SEAS}

The Indian Ocean covers a central point on the world map, when linked with respect to the hot spots of Mediterranean Sea and the South China Sea. While plethora of literature exists on the Indian Ocean and its adjoining seas, it is an ocean that "covers at least one fifth of world's total ocean areas and is bounded by Africa and the Arabian Peninsula" (Albert, 2016). The Indian Ocean and the seas along the Middle East are integral part of the "World Island". The importance of the latter may be observed in the words of Saul Cohen (1963) who claims, "there are, strictly speaking, only two geostrategic regions today: 1) the Trade-Dependent Maritime World, and 2) The Eurasian Continental World. Projecting our views into the future, we anticipate the eventual emergence of a third geostrategic region - the Indian Ocean”. This prediction is further reiterated by William Dowdy and Russel Trood (1983) as they indicate the multifaceted significance that the Indian Ocean holds for countries, the world over. The Indian Ocean region has been assessed from three dimensions, geographic, economic and strategic of interest (Dowdy, Trood, 1983).

Since time immemorial, different waterways have been used for human connectivity and acted as the dominant support of regional, continental and cross-continental trade. Even as today's world celebrates advanced and sophisticated technology in all facets, the sophistication in air communication and mobility is far beyond any imagination of previous centuries. Yet, global commerce and trade via air routes has not outmatched maritime transportation, which is an important aspect of global commerce. Despite the difficulty and risk that characterises shipping of goods across oceans, it nonetheless, remains the "backbone of global trade and the global economy" as nearly "ninety percent of world trade measured by weight and volume is carried in seaborne commerce" (Ki-moon, 2016; Pandya, Herbert-Burns, Kobayashi, 2011; OCED, 2010: 250; Bederman, 2008: 53).

The Indian Ocean and its adjoining sea corridors and straits are the incontestable, important strategic chokepoints of global maritime trade. Aside from being a major conduit for international trade, it is also an intersection of global trade, connecting Northern Atlantic and Asia Pacific on one end and bearing the huge commercial traffic of international energy, all through the Strait of Malacca in Southeast Asia, up until the Gulf of Oman - connecting the Strait of Hormuz and the Bab-el-Mandeb, on the other. Besides its capacity as important petroleum highways, it is also stomaching enormous (nearly 40 percent) offshore minerals and resources (Albert, 2016; Jaishankar, 2016).

These energy chain routes are not simply important to the countries around the routes, they are as much important to the rest of the world, particularly, the countries 
that are growingly becoming huge energy consumers. The water passages are strategically important for the US, China, Japan, Europe, and even India. The security of these 'energy chain routes' is twice as paramount to the energy dependent economies than the actual energy producers. On account of this strategic perspective, William L. Dowdy and Russel B. Trood (1983) outline the variety of linkages, the Indian Ocean manifests. They concur that these linkages are to pursue security policies, strategic coherence, and ensuring military presence, and to safeguard the economic interests of super powers and their allies (Dowdy, Trood, 1983). Naturally, a trade hub such as the Indian Ocean is bound to attract competition within its premises and around.

The super power rivalry in the region has become the instinctive trigger, when port zones of the Indian Oceans are discussed. Literature points out that this rivalry manifested following the withdrawal of the British from the Suez Canal by the end of 1971. Ahmer (1983) argues that during the Cold War, the Soviet Union and United States were the supreme stakeholders in the Indian Ocean, where the former was aiming to counter China and resist Western domination, and the latter was focused on protecting its investments and opposing the Soviet naval build up. More recently, the former Cold War opponents are supplemented by Chinese penetration in the Indian Ocean, which has brewed a neo-Cold War situation in the strategically pivotal maritime commerce of this time.

Premised on the emerging Indian prominence and strategic power, David Brewster (2010) brought New Delhi into the picture of states, scrambling to mark a niche in the Indian Ocean. He discusses the driving motivations behind Indian aspirations in the Indian Ocean. According to Brewster (2010), India aims to develop an expansive maritime strategy, counter China factor in the power equation, and build relations with states around the choke points of the Indian Ocean. Additionally, Pant (2009) talks about the instrumental role of India in the entire maritime affair. The Indian Ocean is a pivotal step for India to rise regionally and globally (Pant, 2009). As the country boons economically and militarily, it has developed enough material capabilities to take a step into the Indian Ocean politics, vis-à-vis her traditional claim over the Ocean. Nonetheless, the work of Jayaramu (1986) gives hope of potential cooperation among the stakeholders present in the Indian Ocean. He believes that "littoral solidarity" may become a prospect to engage peace and prosperity in the region. In this light, the author suggests an increase in cultural and trade interactions, opting for Confidence Building Measures (CBMs), focusing on the political and economic aspect of state relations, and exploring modes of naval cooperation.

In spite of this, the tussle amongst multiple actors either flexing military muscle, competing for regional cooperation or making attempt to create regional consensus on policing the shipping and petroleum highway from harassment and economic jeopardy, generates two perspectives. One, it reemphasises the emerging multipolarism, wherein, for one or two countries (or the great powers) to continue navigating the world in their own image(s) has become increasingly difficult (Dee, 2015). Two, it reiterates Mackinder's view of how important whatever is considered as the "pivotal area" can be marked by competition (Mackinder, 1942: 50; Albert, 2016; Pandya, HerbertBurns, Kobayashi, 2011) and conflict, even when the "pivot area" by no means fall under the sovereign jurisdiction of a particular state; a state, whose interest is 
considered as truncated, jeopardised or undercut might become confrontational, as was the case with Israel and France over Egypt's nationalisation policy of the Suez canal, and this is true for recent U.S aggression towards Iran over an area that falls short from U.S sovereign jurisdiction.

The recent developments in the Indian Ocean and its adjoining seas is reinforcing the strategic importance of the area. However, it is also a fulfilment of Cohen's (1963) prediction, more particularly, it unfolds what this paper dubbed as Complex Power Competition (CPC), elaborated in successive section. These developments hammer the strategic importance of the Indian Ocean and the proclivity of nations; to control the waterways and energy supply and how regional and global powers want the pivot areas to be in their reach and control. The race over the control of the pivot area is not simply to actualise national interest, but to also deprive others from gaining strategic edge in the area.

The unfolding events around the petroleum highways does not simply reinforce the volatility of the region, it underpins the importance of energy to both consumers, producers, transporters, and how paramount is the huge volume of seaborne commerce around the chain routes. The recent bombings along the petroleum highway (at Gulf of Oman near the Strait of Hormuz and Fujairah in the UAE) ${ }^{1}$ underscores the strategic importance of the Indian Ocean and its adjoining shipping lanes. The events are suggestive of two strategic points. One, countries in the region have great dependence on the Persian Gulf shipping lanes (who controls the shipping lanes) and same is true for countries around the world, that depend on the safety of the lanes for smooth passage and energy supply to the rest of the world. Two, energy transporters are equally concerned as expressed in the words of Paolo d'Amico, the chairman of the International Association of Independent Tanker Owners, "Some 30 percent of world's crude oil passes through the Straits... if the waters are becoming unsafe, the supply to the entire Western world could be at risk" (Barrington, Wroughton, 2019).

Iran is accused of perpetuating the two attacks on the Gulf of Oman (near the Strait of Hormuz) and Fujairah in the UAE. Even while there is no concrete evidence suggesting (rather than accusations) that Iran was responsible for the attacks. Jon Alterman elucidate cautiously "There is always the possibility that somebody is trying to blame the Iranians," ... "But there is the greater likelihood that this represents an effort to bolster Iranian diplomacy by creating a perceived international urgency to have the United States and Iran talk" (Barrington, Wroughton, 2019). However, U.S finger pointing appears to have swayed few, as indicated in the language used by observers such as the British Foreign Office minister Andrew Murrison, who holds that the UK believes Iran "almost certainly bears responsibility for the attacks" (BBC, 2019). Meanwhile, the British Foreign Secretary Jeremy Hunt also considered the scenario as "extremely seriously" and that if Iran was involved, "it is a deeply unwise escalation which poses a real danger to the prospects of peace and stability in the region." (Barrington, Wroughton, 2019).

${ }^{1}$ Iran is accused of blowing ships (Kokuka Courageous) in the Gulf of Oman, near the Strait of Hormuz and Fujairah in the UAE. Finger pointing at Iran implicates and underscores the potential of Iran as a state not incapable to disrupt and imperil world's oil market. 


\section{RELEVANCE OF HEARTLAND THEORY AND THE INDIAN OCEAN}

Epistemologically, the utility and applicability of the heartland theory remains puzzling. Amongst political geographers, "It is the ability of Mackinder's original broad model to generate specific policy recommendations that has maintained its popularity to the present day." (Taylor, Flint, 2000). The implication and relevance of the theory today, can be interpreted as tool of rationalisation and strategic thinking upon which state (regional or global) tries to maintain balance of power and more importantly, a strategic calculus for the guarantee that state's economic and commercial interest are not truncated, sabotaged, and undermined. The combination of abundant resources, energy infrastructures, energy gateways and passageways underscore the strategic importance of the Indian Ocean, Persian Gulf, and Arabian Sea. The importance of these water passages buttresses Mackinder's assertion that the world will "forever be divided into two naturally antagonistic sphere - land and sea" (Mackinder, 1943; Clover, 1999: 9) but actual power lies upon whoever can coalesce and dominate the two.

In today's world, these water passageways and gateways are the strategic routes for global oil movement and transportation. The gateways are the global energy life-line and no regional or global power would either relegate, consider with levity or allow other than (itself) to control. The significance of these energy routes and pivot areas reassert Mackinder's second pivot area. According to Mackinder (1943: 598) Central Asia is the first historical pivot area because it provides space for strategic thinking and it from which "horsemen have dominated Asian and European history because of their superior mobility" (Taylor, Flint, 2002: 54). With the dawn of the industrial age and modern ship building, states like Britain dominated the waterways and were accessible to zones, which according to Mackinder became the second pivot area of control. The crux of Mackinder's theory can be situated in the control of land and water. In today's global economy, oil and gas remain the principal energy for global industrial and domestic production; the large amount of global oil and gas passes through the Arabian Sea, Persian Gulf and the larger Indian Ocean.

Mackinder's strong geopolitical instinct identified East Europe as the strategic route to the heartland, but contemporary geopolitical reality denies Mackinder a passing mark on that. The heartland today is penetrable through more 'cost effect strategic route' as demonstrated by BRI, though the importance of the world island (which includes the areas of the Indian Ocean and adjoining seas) remains actively relevant.

The heartland theory was conceived as a grand strategy with many dimensions for the British Empire. The grand strategic analysis tapped Central Asia as the strategic 'energy' heartland of the world and whoever dominates it, could rule the world. In today's geopolitical, energy and strategic environment, the heartland transcends the Central Asia, it can safely be argued that it includes the Middle East - outer or insular crescent, given its abundance in energy reserves. As part of its multidimensional approach, the heartland theory conceived and identified a number of major potential threats to the British Empire. The rising industrial challenge posed by Germany on the one hand and Russia's Eastwards and Southwards expansionism on the other, which produced many zones of potential conflict, upon which the 'Great Game' was shaped and the zones later constituted strategic concern for the British Empire (Mackinder, 
1943; Hall, 1955; Sidaway, 2001: 228; Venier, 2004: 331; Bassin, Aksenov, 2006: 101-102).

Today's geopolitical game is distinctively different and being played out by different actors. Unlike when it was Britain vs. Germany, it is now China-US rivalry. Today, the rise of China as an economic powerhouse is seriously being monitored by the Western powers, particularly the United States. China's global economic proliferation and growth could be likened to Germany of $20^{\text {th }}$ century. In recent years, Washington's policy towards Beijing is not un-similar to how Britain strategically construed Germany as strategic threat. This could also be true by the degree of US efforts in the Indian Ocean that attempt to truncate Chinese BRI which cuts across spectrum of lands and seas.

While on one hand, the Belt and Road Initiatives (BRI) is making attempt to demystify the old Mackinderian land/sea conflict through various forms of connections, on the other hand, the actions of nation around the Outer or Insular Crescent - principally in the Indian Ocean and adjacent water passages would want to keep the rivalry alive. The BRI has not simply positioned China as a formidable and reckonable economy, it also presents China's global strategy geared at connecting many parts of the world. Like every global strategy, the BRI has not been immune from the apprehension of neo-colonialism, even though such sentiment has not ceased to punctuate international headlines every now and then. BRI is China's economic expansionism geared at the revival of the old Silk Road (Osiewicz, 2018). While the old road was principally land routes, the new imagination and reconstruction of Silk Road by China includes land, rail and sea routes.

With BRI, China plans to connect borders, link the world, and weave global economies around itself - positioning itself as the future centre of global economy. If situated in Mackinder's original thesis, BRI demonstrates that China combines the ability to bring the land and sea routes under its "dominion", what in the past, most great powers could not, save for Britain (Hall, 1955) and whoever would maintain this ability will have a decisive geopolitical status in the $21^{\text {st }}$ century and beyond. With BRI, China is not only expanding economically and commercially, the Asian giant is in the business of construction of bases and seaports in many parts of the world, particularly around the Indian Ocean, considered as a threat to Western economic interest. BRI allows China to flex sea power, penetrate the hinterland through a network of railways, connect the world's important land and water routes - encompassing most part of the world - and shaping global commerce in line with China's global geostrategic worldview.

China has made remarkable footing and presence in Djibouti, Tanzania, Pakistan, Bangladesh, Maldives, Myanmar, Sri Lanka, and etc. These are strategic and importance seaports and bases along the Indian Ocean and Arabia Sea. While all of these ports and bases have salient strategic calculation for China, the Gwadar port, situated in Pakistan's province of Baluchistan is quite interesting and requires special attention, particularly in the context of the heartland theory.

China-Pakistan relations is generally dubbed as an all-weather friendship since the early 1950s. The relations between the two countries is consolidated on many fronts, but the agreement to jointly work on China-Pakistan Economic Corridor (CPEC) rais- 
es the profile of their relations to the next level of strategic cooperation. In recent years, CPEC and Gwadar seaport development have been awash by multiple debates, but none appears to be cognizant of the importance of CPEC and Gwadar, beyond the three generic and convenient analysis of connectivity, economic generation, and game changer. CPEC and the economic development in Gwadar is connected with Pakistan's northern area, which connects China through Pakistan with the Central Asian Republics (CARs) - the original "pivot area" in Mackinder's heartland theory. CPEC under the banner of BRI will connect China with the CARs, though that would not be China's first attempt to connect, explore, and exploit the resources of the CARs. In the postSoviet era, Beijing's foreign policy towards the region has been carefully thought out and steadily unfolding (Scott, Alcenat, 2008). Through CPEC, China is not unlikely to penetrate deeper and mark a better footing in Mackinder's pivot area.

Strategically, CPEC and the Gwadar seaport development carry huge implications. Both projects mean China is not only trying to dominate the Indian Ocean (a major economic and commercial waterway), it is also making serious and concerted effort into the heartland through the transitory opportunity provided by Pakistan. While, China might be the major gainer, Pakistan will also have strategic edge as China will be penetrating and connecting the "pivot area - of Central Asia", which according to Mackinder would remain the "pivot of the world politics" (Venier, 2004), through Pakistan. Strategically, Islamabad will earn the dividends and credit for being instrumental for the manifestation of such strategic reality. Thus, it will be the second time Pakistan is instrumentally connecting China with the rest of the world, as was the case in the process of rapprochement between China and the US, during the 1970s (Panda, 1997; Afridi, Bajoria, 2010; Ahmad, 1981).

\section{THE EMERGING COMPLEX POWER COMPETITION (CPC) SURROUNDING THE INDIAN OCEAN}

Having established the applicability of Mackinder's theory in the contemporary (upper and lower) Indian Ocean affairs, the interplay of state politics and economy along the sea routes, and linking the two aspects together, the paper arrives at a juncture where it lays out the Complex Power Competition (CPC) unfolding in the Indian Ocean milieu. The military energy of each state in the power puzzle of Indian Ocean is indicative of their motivation to rise over the other. Their presence at the various ports and bases in the Indian Ocean are instrumentally counter balancing the power index of each other. All the while, contributing towards the rise of a multipolar competitive quandary where economic cooperation and strategic counter balance runs side by side.

The benevolently crafted presence of extra-regional countries over the ports are not for mere geo-economic mileage, but in the hindsight, this contemporary competitive advantage seeking is articulated on military lines as well. Such countries often do not project a prominent military handle in other countries because of the international cordial image that they seek to maintain. Therefore, economic pebbles are thrown out prominently by China, US, Russia, and India on ports in the Indian Ocean and the 
Persian Gulf to legitimize their interests over respective ports in the region (as need based convertible military bases). For China, one may regard these interchangeable politics as an imperative step for her BRI, its trade reorientation towards the Strait of Hormuz, her goals to establish a 'Community of Common Destiny', and positioning of soft military flags across the region. While for the US-Indian alliance, the driving force is to counter Chinese influence, to oversee Chinese activities in the Indian Ocean and beyond - South China Sea and the greater Asia Pacific region, and contribute effectively to elevate their power status in the Indian Ocean (and consequentially, dominate maritime trade and commerce). Finally, presence of Russia is primarily for political relevance in the region and securing itself a strategic place in the entire maritime power conundrum (Centre for Strategic Assessment and Forecasts, 2001).

Since military presence has now become increasingly meaningful and important as a proxy political strategy, the result spurs out as an emerging complex power competition. This not only aids in additional deterrence of the respective country present in the area, but it also assists in the expansion of political influence and keeping the other countries in check. The International relations over water bodies are governed by warm water currents and the respective economic and strategic choke points. As the Strait of Malacca becomes more conflictual, attention is shifted towards the Strait of Hormuz for peaceful movement and shorter sea routes. However, the irony surrounding this peaceful transit route is that it is being supervised by competing countries with divergent interests in the region and even more volatile than the Strait of Malacca. As the scope of the Strait of Hormuz widens, the geo-economic market in the region also attracts more attention of foreign countries. This gives the external powers to choose their proxy locations for economic opportunities, as they employ their military postures in those respective areas.

In this purview, the economic circumstances have pushed United States to invest its political and military energy around the choke point areas and economic zones in the Persian Gulf and Indian Ocean region. For this purpose, she has aimed at fostering coalitions and partnerships with regional governments that provide favourable alliances and strategic positioning to further US objectives in the area.

Tracing its route, US presence in the shape of military (bases, repairs/maintenance and training), economic (logistics, fuel and food) and diplomatic ports are observed at different check points of the region. More recently, it is observed that political proliferation of interests (in the Indian Ocean) has converged to the integral joint - the Gulf of Oman - for US as well as a few other countries.

Oman being the welcoming point of the Strait of Hormuz, is now emerging as a potential point of interest for competitive military bases at the prominent port locations of Duqm, Salalah and Sohar. Oman has been an explicit military partner of United States through the 'Oman Facilities Access Agreement' signed by the two countries in 1980, and renewed in 2010 (Katzman, 2016). Being at a strategically significant location at the Western Indian Ocean, Oman has recently opened her arms to Britain's joint defense agreement over the Greenfield port at Duqm on $21^{\text {st }}$ February, 2019 (Ministry of Defence UK, 2019). This move is an addition to the already developed Joint Logistics Support Base as Britain's Naval Outpost on $27^{\text {th }}$ November, 2018 at Duqm (The Maritime Executive, 2019). 
The military interactions with US and UK is accompanied by other countries like India, who has signed a memorandum of understandings (MoU) with Muscat on $11^{\text {th }}$ February 2018 (Times of Oman, 2018). This MoU will facilitate the visit of Indian military vessels at the Duqm port for services and maintenance, The Indian military presence at Oman and their respective engagements on military equipment is ushered by her interest to develop a good relationship with Oman, in order to oversee Chinese strategic assets in the Indian Ocean.

China on the other hand, plans to invest heavily in Oman's non-oil economy at port Duqm. The Chinese driven BRI is therefore, promising for Oman since it ensures cooperation between the two countries in constructing an industrial park at Duqm port (Xi, Yuanyong, 2018).

In addition, the Salalah and Sohar port are marked as other points of transport, shipping and logistics hub in Oman's development plan, and will prove to boost manufacturing and export capabilities of Oman. The service portfolio of Oman will expand under these two ports, and greater economic diversification (that includes aluminium and steel smelting, pharmaceuticals, textiles, food production and storage, and mining industry) will be achieved at these naturally positioned points of leverage. This indicates a symbiotic relationship being shared by Oman with US, UK, India and China and more particularly the manifestation of complex power competition. Economic motivations at the forefront provides these foreign countries an arrangement to manoeuvre their military mobility in those areas. Oman provides them with the military base point at an integral junction, while Oman itself seeks the political boost and recognition that it desires through such benefactors. This desire is in line with Oman's Vision 2040 Development Plan which seeks economic diversification for Oman through investments and projects that focus on fostering a non-oil economy (agriculture, tourism, start-up ecosystems, technology and free industrial zones) for Oman (Ministry of National Economy, 2016).

Apart from Oman, other examples of complex power competition are characterised by US presence and interest on foreign ports include; Djibouti (North East Africa), Fujairah (UAE), Jabel Ali (UAE), Jeddah (Saudi Arab), Karachi (Pakistan), Khalifa (Abu Dhabi), Mina Zayed (Abu Dhabi), Khalifa bin Salman (Bahrain), Mina Salman (Bahrain), Trincomalee (Sri Lanka), Madagascar, Maldives, and Port Victoria (port call in Seychelles). The current geo-politics of the region shares resemblance with US and Soviet relations between 1968 to 1991. During the era, the two polar powers competed for maritime access, political influence, allies, and bases in the region in question. Presently, all the US efforts towards regional maritime hegemony is a response to Chinese aspirations in the region. For example, the recent joint naval exercise of US and Sri Lanka has a symbolic flavour to it; it not only displays US strategic interest to counter balance Chinese presence in at Hambanatota port, but it also gives Sri Lanka a chance to demonstrate that control of the port still resides with the country itself (The Economic Times, 2019), hence complex power competition.

China is ardently extending its string of pearls across the Persian Gulf and Indian Ocean region. As discussed earlier, the Chinese sponsored BRI has established a web of economic, military and political influence. Under the BRI, Chinese sea lines of communication (SLOCs) are met with competition by US and India (which is a strong 
partner of US in the region), that act as power brokers in the region of interest. This neck to neck competition between Washington and Beijing in the region, simultaneously promotes and reduces the risk of a Thucydides Trap. The presence of India in the region under discussion is defined by Rahul Roy Chaudhury (2018) as 'a relationship of energy, expatriates, and economy'. Under this definition, it is observed that $42 \%$ of Indian oil imports is dependent upon the six Gulf Cooperation Council states (GCC). Additionally, Liquefied Natural Gas (LNG) is dominantly imported by India from Qatar. As for expatriates; UAE, Saudi Arab, and Kuwait holds the largest expatriate community of India, and the total amounts to approximately 7.6 million in the region (World Economic Forum, 2018). While in terms of trade partnership with the GCC countries, India's imports ranged to around $\$ 79.70$ billion, while her exports totalled at $\$ 41.55$ billion, as per latest data (Mathew, 2019). This emergent interdependency has created space for Indian competitive advantage, as economic and political compulsions hammer her influence in the area. The influence of New Delhi might not be equally swaying as that of Washington and Beijing, nonetheless, the action of New Delhi demonstrates, it has the propensity to flex muscles as a competitive player amongst others.

As for maritime engagements in the Persian Gulf and Indian Ocean, India not only acts as a watchdog (and partner) for US but also aims to extend her sphere of influence. Indian presence alongside US is witnessed at Duqm (Oman), Salalah (Oman), Jeddah (Saudi Arab), Jubail (Saudi Arab), and Port Victoria (port call in Seychelles), in a diplomatic, training and military exercising capacity. While she is present alongside China at the ports of Bandar Abbas (Iran), Jeddah (Saudi Arab), Maldives, and at (as previously mentioned) Salalah (Oman).

Another important player that is aiming to revive its power status (within the Indian Ocean) for geo-economic and strategic positioning is Russia. As a competitor, Moscow takes a premium in being part of the players that controls and benefit from the major water passages along the Indian Ocean and Arabia Sea, which is clearly and understandably important for Russia's national interest and security, documented in the Maritime Doctrine of Russian Federation. Moscow has developed presence for diplomacy, logistics, and military training at Bandar Abbas (Iran), Djibouti, Madagascar, Salalah (Oman) and Syria.

Bringing other stakeholders of the Indian Ocean into the limelight, a base race is observed in certain African countries (Djibouti, Tanzania, and Eritrea, Madagascar, Seychelles) that lay at the outer rim of the Indian Ocean. Turkey, France, Italy and Japanese (along with US, China and Russia) have a concentrated presence in the area. This confluence is a typical representation of complex power competition that the paper has aimed at identifying and establishing. It is essential to observe at this juncture that the political congestion at Gulf of Aden (Eritrea and Djibouti) and Gulf of Oman indicate the key importance of these transit points in the region. Both Gulfs are the gateways and economic choke points that flow into the Indian Ocean, hence, the saturation manifests a complex maritime affair for power in the region.

Keeping the ocean save from maritime hoodlum, such as the once upon a time Somalia piracy, ensuring that international waterways are free from all sort of threat, protecting national economic and commercial interest, and more particularly prevent- 
ing a monopolistic or oligarchic dominance of the ocean, offers a holistic delineation of power competition around the Indian Ocean and its adjoining seas. In this manner, the economic sensibilities are utilised by all stakeholders in the region to orchestrate their power impulses.

Figure 1. The important ports and multi-plex hub and spoke system of Indian Ocean

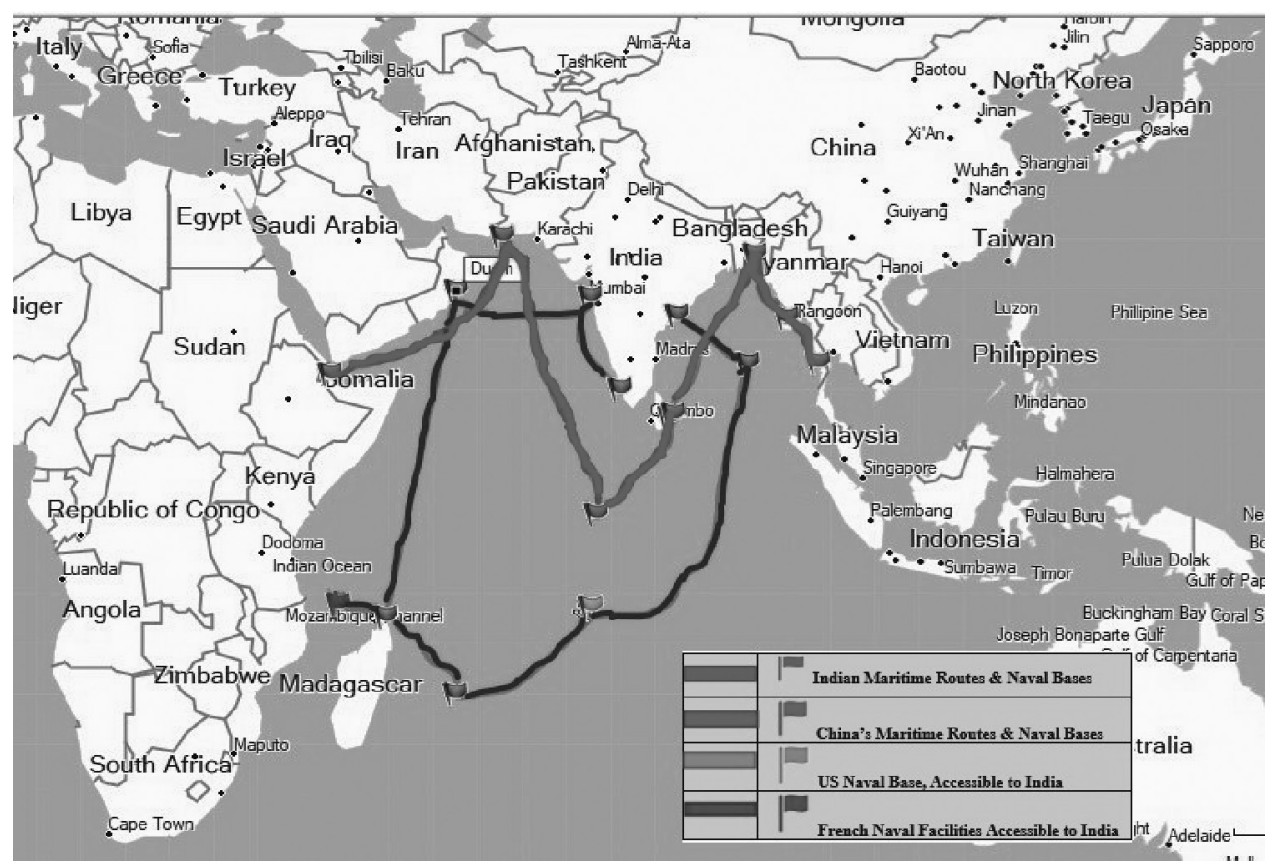

Source: Authors own elaboration using the Mapsource software.

Conceptually, these port points of various countries may be portrayed as a 'multiplex hub and spoke system' upon which countries compete for power and influence. The hub and spoke principle is commonly understood as a transportation system of commodities from one point of collection (spoke) to the central unit (hub). Employing this paradigm to the competitive politico-economic engagement in the region, the $h u b$ is observed to be the respective deployment of military and economic ports in the region of influence from which spokes of strategic surveillance spur out. This denotes to a network of strategic influence and geo-economic and geo-political counter balance in the Indian Ocean.

The laid out practice of stakeholders in the Persian Gulf, and the larger Indian Ocean reiterate the paper's position - Mackinder's original pivot area has shifted to Indian Ocean region, in the context of contemporary maritime politics, however, his assertion that countries compete to dominate the world islands still stands true. This recapitulation highlights the relevancy of Mackinder's heartland theory in the present power theatre of Indian Ocean region; since China has emerged as a significant economic puppeteer, India's trade and productivity has experienced a steady rise, the exports of raw materials from developing countries has gradually increased, and Middle 
Eastern oil market has expanded widely. These factors recalibrate and re-establish the strategic importance of the entire Indian Ocean region.

The multipolar nature of economic cooperation and military engagements in Mackinder's neo-pivot area authenticates the existence of a complex power competition. Such a power struggle drives countries to develop presence at proxy ports/bases alongside other countries, oversee the activities of their rivals, establish their presence at relevant choke points, and dominate the sea lines of communication (SLOCs), in order to retain their strategic position in the region. Additionally, the stakeholders in the larger Indian Ocean reflect multifaceted layers of interest (infrastructural, oil market, post-oil economy, strategic and military) that have pushed them to create their presence in the region, with the ultimate goal of maritime hegemony. In this context, whoever rules the neo-pivot area (Indian Ocean) will have a direct transit access to the heartland (Central Asia), and whoever rules the heartland will rule the world. Therefore, in contemporary global politics, the supremacy over sea routes is a prerequisite to acquire supremacy over land routes, as was originally propounded by Mackinder.

\section{REFERENCES}

Afridi J., Bajoria J. (2010), China-Pakistan Relations, “Council on Foreign Relations”, https:// www.cfr.org/backgrounder/china-pakistan-relations (28.10.2019).

Ahmad N. (1981), Sino-Pakistan Relations (1971-1981), "Pakistan Horizon”, Vol. 34, No. 3, http:// www.jstor.org/ stable/41393854 (28.10.2019).

Ahmar M. (1983), Politics of Superpower Rivalry in the Indian Ocean, "Pakistan Horizon", Vol. 36, No. 1, https://www.jstor.org/stable/41394719 (28.10.2019).

Albert E. (2016), Competition in the Indian Ocean, "Council on Foreign Relations", https:// www.cfr.org/backgrounder/competition-indian-ocean (28.10.2019).

Barrington L., Wroughton L., U.S. blames Iran for tanker attacks in Gulf of Oman, Iran rejects assertion, "Reuters", https://www.reuters.com/article/us-mideast-tanker/oil-tanker-attacks-ingulf-of-oman-fuel-security-oil-supply-fears-idUSKCN1TE0OI (13.06.2019).

Bassin M., Aksenov K. E. (2006), Mackinder and the Heartland Theory in Post-Soviet Geopolitical Discourse, "Geopolitics", Vol. 11, No. 1, https://doi.org/10.1080/1465004050052412 (28.10.2019).

Bederman D. (2008), Globalization and International Law, Palgrave Macmillan, New York.

Brewster D. (2010), An Indian Sphere of Influence in the Indian Ocean?, "Security Challenges", Vol. 6, No. 3, https://www.jstor.org/stable/26459796 (28.10.2019).

Chaudhury R. R. (2018), India and the Gulf region: building strategic partnerships, "International Institute for Strategic Studies", https://www.iiss.org/blogs/analysis/2018/08/india-gulf-strategic-partnerships (28.10.2019).

Chaudhury R. R. (2018), India's evolving partnership with the Gulf region, "World Economic Forum", https://www.weforum.org/agenda/2018/10/india-s-evolving-partnership-with-thegulf-region/ (28.10.2019).

Clover C. (1999), Dreams of the Eurasian Heartland: The Re-emergence of Geopolitics, "Foreign Affairs", Vol. 78, No. 2.

Cohen S. B. (1963), Geography and politics in a world divided, Random House, New York. 
Dee M. (2015), The European Union in a Multipolar World: World Trade, Global Governance and the Case of the WTO, Palgrave Macmillan, New York.

Dowdy W. L., Trood R. B. (1983), The Indian Ocean: An Emerging Geostrategic Region, "International Journal”, Vol. 38, No. 3, https://www.jstor.org/stable/40202160 (28.10.2019).

From defence to space, Oman, India sign a clutch of MoUs, “Times of Oman", https://timesofoman. com/article/127976 (11.02.2018).

Government of Oman (2016), A Brief of Vision for Oman's Economy - 2020: Long-Term Development Strategy (1996-2020), Ministry of National Economy, https://www.scp.gov.om/PDF/ NinthFiveYearPlan.docx (28.10.2019).

Hall A. R. (1955), Mackinder and the Course of Events, "Annals of the Association of American Geographers", Vol. 45, No. 2.

Jaishankar D. (2016), Indian Ocean region: A pivot for India s' growth, “Brookings”, https://www.brookings.edu/opinions/indian-ocean-region-a-pivot-for-indias-growth/ (28.10.2019).

Jayaramu P. S. (1986), Indian Ocean as a Zone of Peace: Problems and Perspectives, "The Indian Journal of Political Science", Vol. 47, No. 2, https://www.jstor.org/stable/41855848 (28.10.2019).

Katzma K. (2016), Oman: Reform, Security, and U.S. Policy, Congressional Research Service, https://fas.org/sgp/crs/mideast/RS21534.pdf (28.10.2019).

Ki-moon B. (2016), Maritime Transport Is 'Backbone of Global Trade and the Global Economy', Says Secretary-General in Message for International Day, "UN Press Release”, SG/ SM/18129-OBV/1663-SAG/486, https://www.un.org/press/en/2016/sgsm18129.doc.html (22.09.2016).

Maritime Doctrine of Russian Federation 2020, approved by the decree of Vladimir Putin, President Russian Federation, Pr-1387 (2001), Centre for Strategic Assessment and Forecasts, http:// csef.ru/en/politica-i-geopolitica/510/morskaya-doktrina-rossijskoj-federaczii-na-period-do2020-goda-7984 (28.10.2019).

Mackinder H. J. (1904). The Geographical Pivot of History, "The Geographical Journal”, Vol. 23, No. 4.

Mackinder H. J. (1942), Democratic Ideals and Reality: A Study in the Politics of Reconstruction, Constable Publishers, London.

Mackinder H. J. (1943). The Round World and the Winning of the Peace, "Foreign Affairs", Vol. 21, No. 4, https://www.jstor.org/stable/2002978 (28.10.2019).

Mathew J., India reports robust growth in trade with Gulf region, "Arabian Business”, https://www. arabianbusiness.com/politics-economics/419185-india-reports-robust-trade-growth-withgulf-region (1.05.2019).

Meinig D. W. (1956), Heartland and Rimland in Eurasian History, "The Western Political Quarterly", Vol. 9, No. 3.

Minister urges Iran to stop attacks in Gulf of Oman, "BBC", https:/www.bbc.com/news/uk48738717 (24.06.2019).

OECD (2010), Globalisation, Transport and the Environment, "OECD Publishing”.

Osiewicz P. (2018), The Belt and Road Initiative (BRI): Implications for Iran-China Relations, "Przegląd Strategiczny", Vol. 8, No. 2.

Panda D. (1997), The United States and China: Towards A Rapprochement, "Indian Journal of Asian Affairs", Vol. 10, No. 2.

Pandya A. A., Herbert-Burns R., Kobayashi J. (2011), Maritime Commerce and Security: The Indian Ocean, Stimson Centre, Washington DC. 
Pant H. V. (2009), India in the Indian Ocean: Growing Mismatch between Ambitions and Capabilities, "Pacific Affairs", Vol. 82, No. 2.

Scott M., Alcenat W. (2008), Revisiting the Pivot: The Influence of Heartland Theory in Great Power Politics, "Macalester College", http:/www.creighton.edu/fileadmin/user/CCAS/departments/PoliticalScience/MVJ/docs/The_Pivot_-_Alcenat_and_Scott.pdf (28.10.2019).

Sidaway J. (2001), Geopolitics: Twentieth Century Spectre, “Geographical Association”, Vol. 86, No. 3, https://www.jstor.org/stable/40573579?seq=1\#metadata_info_tab_contents (28.10.2019).

Taylor P., Flint C. (2000), Political Geography: World-Economy, Nation State and Locality, Pearson Education, Delhi.

The Asia-Pacific Maritime Security Strategy: Achieving U.S. National Security Objectives in a Changing Environment (2015), "US Department of Defense", https://dod.defense.gov/ Portals/1/Documents/pubs/NDAA\%20A-P_Maritime_SecuritY_Strategy-08142015-1300FINALFORMAT.PDF (28.10.2019).

UK and Oman sign historic Joint Defence Agreement, "Ministry of Defence", https://www.gov.uk/ government/news/uk-and-oman-sign-historic-joint-defence-agreement (21.02.2019).

UK Secures Naval Base in Oman, "The Maritime Executive”, https://www.maritime-executive.com/ article/uk-secures-naval-base-in-oman (21.02.2019).

US-Sri Lanka naval exercise at port managed by China, "The Economic Times", https://economictimes.indiatimes.com/news/defence/us-sri-lanka-naval-exercise-at-port-managedby-china/articleshow $/ 68986125 . \mathrm{cms}$ ?from $=$ mdr\&utm_source $=$ contentofinterest\&utm medium=text\&utm_campaign=cppst (22.04.2019).

Venier P. (2004), The Geographical Pivot of History and Early Twentieth Century Geopolitical Culture, "The Geographical Journal", Vol. 170, No. 4.

Weigert H. W. (1945-46), Mackinder's Heartland, "The American Scholar”, Vol. 15, No. 1.

Xi L., Yuanyong Y., Spotlight: China, Oman establish industrial park to boost bilateral cooperation, "Xinhuanet", http://www.xinhuanet.com/english/2018-12/19/c_137683272.html (19.12.2018).

\begin{abstract}
Competition amongst great powers is not new in international politics. It has traditionally been the driving force for the creation and collapse of empires and states. In the $19^{\text {th }}-20^{\text {th }}$ centuries, the British Empire established its dominion in the world over and maintained an uncontested global supremacy. To secure Britain's global dominance, in 1904, Sir Halford Mackinder dazed the world with his heartland theory. Ever since then, the theory remains one of the most discussed geopolitical theories. The article does not pretend or oblivious of the heaps of criticism Mackinder's theory has received over several decades, it nonetheless, employs the theory in the context of the contemporary international political environment, with particular reference to the happenings around the Indian Ocean, Persian Gulf, and Arabian Sea. So therefore, the point of analysis here centres around the applicability of the theory and the implications posed by Mackinderian geographical rationalisation in formulating foreign policy around what the article considers as the contemporary pivot area - the Indian Ocean. Through the theoretical understanding of Mackinder's thesis, the article argues that the Indian Ocean and its adjoining seas corridors and Straits are 'pivot areas' potential enough to generate competition amongst regional and global powers. The new 'pivot areas' is enormously endowed with natural resources and is the major energy highway(s), upon which global econ-
\end{abstract}


omies are dependent. The article concludes by arguing that a complex power competition (CPC) is brewing along the neo-pivot region.

Keywords: Mackinder's Heartland theory, Indian Ocean, complex power competition, geoeconomics, geo-politics, geo-military

\section{PRZEGLĄD TEORII HEARTLANDU MACKINDERA: STWIERDZENIE POWSTANIA ZJAWISKA KOMPLEKSOWEJ KONKURENCJI ENERGETYCZNEJ W REGIONIE OCEANU INDYJSKIEGO}

\section{STRESZCZENIE}

Zjawisko konkurencji między wielkimi mocarstwami nie jest w polityce międzynarodowej niczym nowym. Konkurencja zawsze napędzała powstawanie i upadki imperiów i państw. W XIX-XX wieku Imperium Brytyjskie zapewniło sobie światową dominację i utrzymało niekwestionowaną supremację globalną. Aby zapewnić dalszą globalną dominację Wielkiej Brytanii, w 1904 roku Sir Halford Mackinder zadziwił świat swoją teorią „heartlandu”, która pozostaje jedną z najczęściej dyskutowanych teorii geopolitycznych. Zdając sobie sprawę z głębokiej krytyki, jakiej przez kilka dziesięcioleci poddawano teorię Mackindera, artykuł wykorzystuje ją jednak w kontekście współczesnego międzynarodowego środowiska politycznego, ze szczególnym uwzględnieniem wydarzeń w rejonie Oceanu Indyjskiego, Zatoki Perskiej i Morza Arabskiego. Dlatego też analiza koncentruje się tutaj na możliwościach zastosowania teorii i implikacjach wynikających z racjonalizacji geograficznej Mackindera w formułowaniu polityki zagranicznej wokół tego, co artykuł uważa za współcześnie kluczowy obszar (pivot area) - Ocean Indyjski. Teoretyczna interpretacja tezy Mackindera dowodzi, że Ocean Indyjski i sąsiednie korytarze morskie i cieśniny są „kluczowymi obszarami”, których siła stymuluje konkurencję między potęgami regionalnymi i światowymi. Nowe „obszary kluczowe” są niezwykle bogate w zasoby naturalne i stanowią główne szlaki energetyczne, od których zależą gospodarki globalne. Artykuł kończy konkluzja, że w nowym regionie kluczowym wykluwa się kompleksowa konkurencja energetyczna (complex power competition $(C P C)$ ).

Słowa kluczowe: teoria Heartlandu Mackindera, Ocean Indyjski, złożona konkurencja energetyczna, geoekonomia, geopolityka, geobezpieczeństwo 